\title{
Protein tyrosine phosphatases in cardiac physiology and pathophysiology
}

\author{
Fallou Wade ${ }^{1} \cdot$ Karim Belhaj ${ }^{2} \cdot$ Coralie Poizat $^{1,3}$ \\ Published online: 2 February 2018 \\ (C) The Author(s) 2018. This article is an open access publication
}

\begin{abstract}
More than any other organ, the heart is particularly sensitive to gene expression deregulation, often leading in the long run to impaired contractile performances and excessive fibrosis deposition progressing to heart failure. Recent investigations provide evidences that the protein phosphatases (PPs), as their counterpart protein kinases, are important regulators of cardiac physiology and development. Two main groups, the protein serine/threonine phosphatases and the protein tyrosine phosphatases (PTPs), constitute the PPs family. Here, we provide an overview of the role of PTP subfamily in the development of the heart and in cardiac pathophysiology. Based on recent in silico studies, we highlight the importance of PTPs as therapeutic targets for the development of new drugs to restore PTPs signaling in the early and late events of heart failure.
\end{abstract}

Keywords Protein tyrosine phosphatase $\cdot$ PTP $\cdot$ Cardiac hypertrophy $\cdot$ Heart failure $\cdot$ Small-molecule inhibitor

\section{Introduction}

Cardiac physiology is heavily dependent on the intracellular signaling balance between protein kinases (PKs) and their counterparts, the protein phosphatases (PPs). Not surprisingly, the deregulation of such balance in the adult heart leads in most cases to heart dysfunction associated with impaired contractile performances and fibrosis deposition often leading to heart failure [1-4]. In the past decade, the signaling cascades of numerous PKs and their partners in mediating pathological cardiac hypertrophy and heart failure have been extensively studied and reviewed from investigations performed in cellular models and in genetically modified mice (reviewed in [5-7]). However, proportionally, the role of PPs in the development of myocardial disorders has been much less

Coralie Poizat

coralie.poizat@gmail.com

1 Cardiovascular Research Program, King Faisal Specialist Hospital and Research Centre, PO Box 3354, Riyadh 11211, Saudi Arabia

2 College of Medicine and Health Sciences, Al-Faisal University, Riyadh 11211, Saudi Arabia

3 Biology Department, San Diego State University, San Diego, CA 92182, USA documented $[8,9]$. This is mostly due to historical reasons as PPs were discovered 10 years after PKs [10, 11]. Over the past decades however, it has become clear that PPs are specific regulators that play active roles in coordinating with PKs the regulation of many physiological processes. The PPs can be divided into two main groups, which are the protein serine/threonine phosphatases (PPPs) and the protein tyrosine phosphatases (PTPs). The PPPs constitute the majority of the PPs and target phosphoproteins on their serine and/or threonine residues. The three most documented PPPs in the heart are protein phosphatase 1 (PP1), protein phosphatase 2A (PP2A), and protein phosphatase 2B (PP2B) also known as calcineurin. Mechanisms by which PPPs regulate $\mathrm{Ca}^{2+}$ homeostasis and cardiac function are well documented in human and animal models of heart failure [12-14]. Since PPPs have been the topic of many excellent reviews, they will not be discussed in this review $[9,15,16]$. The PTPs dephosphorylate tyrosyl residues in proteins $[17,18]$ with the majority of PTPs being active enzymes and as abundant as protein tyrosine kinases (PTKs) [10]. Here, we summarize the role of the PTPs in heart development and cardiovascular diseases, particularly their effect on cardiac hypertrophy and how their dysregulation progresses to heart failure. Finally, we discuss the inhibitors of PTPs and their therapeutic potential for the treatment of heart disease in human. 


\section{Protein tyrosine phosphatase family and substrate specificity}

In human, more than 100 genes encode for the PTPs among which 81 are active phosphatases [10, 19, 20]. The PTPs constitute a large family of enzymes, many of which harbor a transmembrane domain and a variable ectodomain (for review, see [21-23]). All PTPs share a common signature motif (HCXXGXXR) responsible for the enzyme activity. The PTP superfamily can be divided into four classes based on their cellular localization/catalytic domains: the receptor-like PTPs (rPTPs), the non-receptor PTPs (nrPTPs), the low molecular weight PTP (LMWPTP), and the VH-1 and CDC-25 groups [10, 24-27]. A different classification of PTPs exists based on their amino acid sequence and catalytic domain, which groups them into four classes (reviewed in [10]). Class I includes rPTPs and nrPTPs also known as "classical" pTyr-specific PTPs. These comprise 38 PTPs, and VH1-like "dual-specificity" PTPs (DUSPs) which are very divers with 61 members able to dephosphorylate pTyr and pSer/pThr residues. Class II PTP has a single member, the LMWPTP that targets substrates specifically on their Tyr residues. Class III PTPs include three "dual-specific" Cdc25 enzymes, while class IV is represented by Eya proteins with pTyr or dual pTyr/pSer activity.

Tyrosine phosphorylation process mediates most if not all cell signaling processes including growth, differentiation, survival, and death [28]. In the early 1990s, the PTPs were mainly considered as housekeepers or passive players in the cell $[10,11]$. After considerable efforts in the field, it is now recognized that PTPs are critical regulators of cell signaling. Deregulation of their expression or activity can compromise cell physiology and hence lead to diseases [29]. The importance of PTPs in regulating signaling pathways was first illustrated by the discovery of CD25, (a DUSP) and SHP2, which can positively regulate signaling by increasing the phosphorylated level of a tyrosyl site of PTK [30-33]. PTPs act as important regulators of tyrosine phosphorylation in many cell types including cardiac cells [34, 35].

\section{Role of PTPs in cardiac development and diseases}

Out of the 107 human genes encoding PTPs, very few have been reported to have a role in the cardiovascular system. Up to this date, the PTPs implicated in cardiac development and disease include the protein-tyrosine phosphatase 1B (PTP1B), the Scr homology-2 (SH2) domain-bearing non-transmembrane protein tyrosine phosphatase (SHP2), and the LMWPTP (Fig. 1). Recent studies used genome-wide siRNA/shRNA screening and proteomics approach to identify novel roles and substrates of PTPs in human pathologies [36].
This powerful technology will be useful and adaptable for investigators to discover new PTPs implicated in human cardiovascular diseases. Below, we summarize mechanisms by which these PTPs regulate cardiac contractility and their role in heart development and disease (Table 1).

\section{PTP1B}

The protein-tyrosine phosphatase 1B (PTP1B) is a nontransmembrane PTP with a wide tissue distribution and expressed mainly in the endoplasmic reticulum (ER) via its C-terminal domain [49]. PTP1B binds directly to PTK receptors including the insulin receptor (IR) and epidermal growth factor (EGF) receptor [50-53]. PTP1B is a key negative regulator of both insulin and leptin pathways ([54, 55] for review). Genetic deletion of PTP1B in mice results in insulin sensitivity and protects mice against high-fat diet-induced obesity $[52,56$, 57]. High-fat diet-induced obesity increases the risk of hypertension and cardiovascular disorders, although the mechanism of action is unknown [58, 59]. Insulin resistance is strongly associated with oxidative stress, cardiac aging, and cardiomyocyte contractile dysfunction. Consistent with the effects of obesity and insulin on the cardiovascular system, PTP1B has emerged as a key regulator of obesity-induced cardiovascular disorders (recently reviewed in [39]).

Early studies using cardiac overexpression of antioxidant enzymes and dietary models documented reduced Akt expression and phosphorylation associated with increased PTP1B cardiac expression, suggesting a role of PTP1B in cardiac function [60, 61]. Enhancement of PTP1B was associated with impaired cardiac contractile and intracellular $\mathrm{Ca}^{2+}$ dysfunction [52, 60, 61]. As expected, PTP1B overexpression correlated with decreased phosphorylation of the IR (Tyr1146) and Akt after insulin stimulation in advanced cardiac aging and pre-diabetic insulin resistant hearts [60, 61]. Gomez and colleagues established the role of PTP1B in heart failure when they showed that mice with gene deletion or specific inhibition of PTP1B are protected against cardiac contractile dysfunction and heart failure after myocardial infarction. Improved heart function correlated with reduced fibrosis and hypertrophy while infarct size did not appear to change [38] (Table 1). In line with this study, recent findings showed that mice genetically lacking PTP1B resisted against chronic afterload-induced heart failure via a cardiac improvement of VEGF and angiogenesis signaling [39, 40]. Interestingly, eNOS, which modulates insulin secretion, was reduced in insulin resistant hearts or increased in PTP1Bdeficient mouse hearts [38, 61]. Whether eNOS is directly associated with the insulin signaling is unclear, however the reduction of ROS generation alleviated insulin resistanceinduced contractile dysfunction. PTP1B deletion enhanced capillary density and myocardial perfusion in mice 8-day post-myocardial infarction associated with increased 
Fig. 1 Protein tyrosine phosphatases (PTPs) playing a role in the cardiovascular system. Among the PTPs, three nontransmembrane PTPs have been described with roles in the cardiovascular system: protein tyrosine phosphatase 1B (PTP1B) and Scr-homology 2 domain containing phosphatase 2 (SHP2) belonging to class PTPs, and low molecular weight protein tyrosine phosphatase (LMWPTP), the sole member of class II PTPs

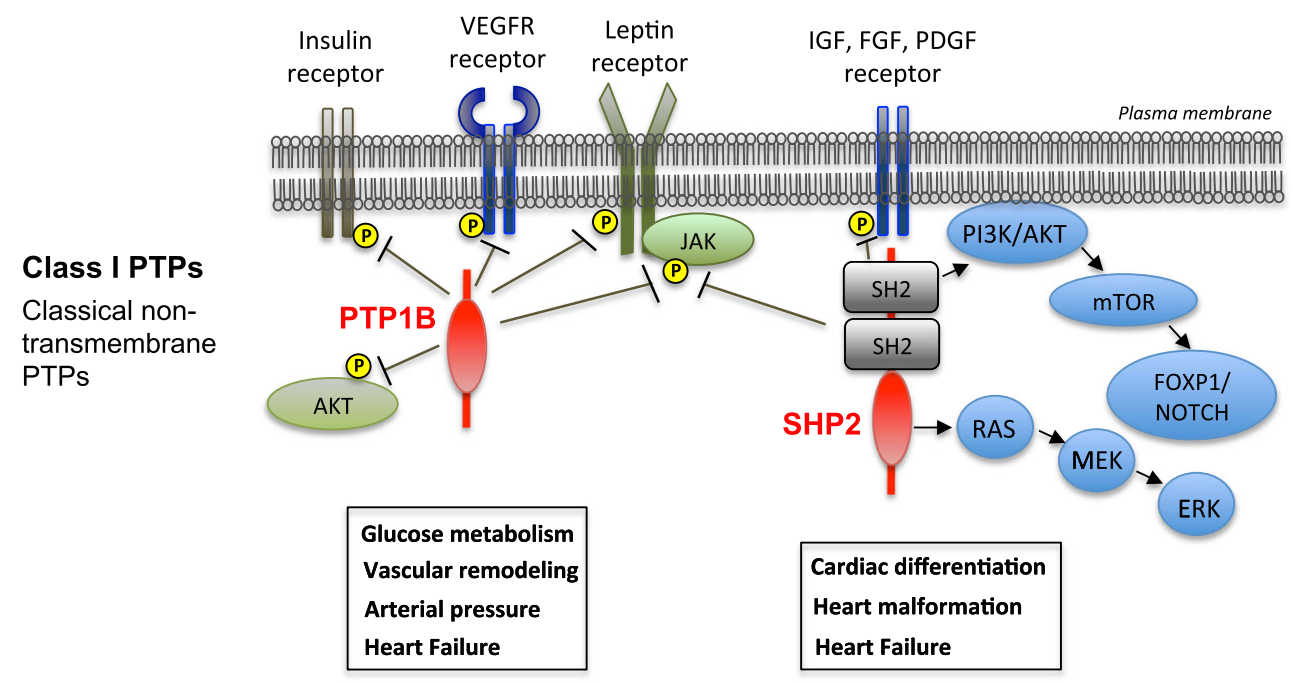

Class II PTPs (1)

Classical nontransmembrane PTPs

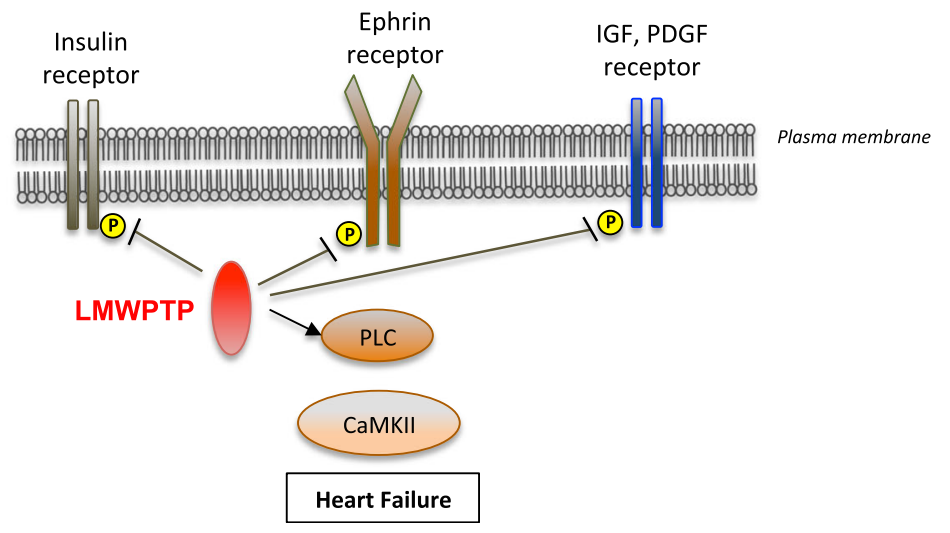

VEGFR2 activity, although no reduction of infarct size was observed. This suggests that the beneficial effect of PTP1B ablation is mostly due to improved vascular remodeling possibly through nitric oxide (NO) [41]. Consistent with this, Panzhinskiy and collaborators reported that ER stress activates PTP1B via ROS-NFkB signaling resulting in insulin resistant in skeletal muscles under high-fat diet condition [52]. Also, endothelial dysfunction associated with diabetes did not occur in PTP1B-deficient mice mostly due to increased cyclooxygenase 2 expression [62]. Collectively, these studies are consistent with a protective role of PTP1B deletion against pathological cardiac and vascular remodeling. This is in contrast with the study by Belin de Chantemele and colleagues, where PTP1B knockout mice exhibited high blood pressure in response to leptin infusion [37]. This study indicates that PTP1B is a modulator of cardiovascular function through its capacity to negatively regulate leptin-induced hypertension possibly through the sympathetic nervous system. Overall, there is clear-cut evidence for a role of PTP1B in heart physiology and pathophysiology. More investigations are needed to define the underlying mechanisms by which PTP1B affects cardiovascular function. In this regard, a signaling of interest not yet elucidated is the alteration of $\mathrm{Ca}^{2+}$ handling through modulation of SERCA2a and NCX1 by PTP1B in the heart. Dysregulation of the sarco/endoplasmic reticulum $\mathrm{Ca}^{2+}$-ATPase (SERCA2a) and NCX1 expression impair cardiac contractility. In cancer, targeting of $\mathrm{Ca}^{2+}$ signaling has been proposed as an alternative therapy to treat human cancer patients [63]. The use of animal models lacking or overexpressing PTP1B and cellular models with genetic siRNA targeting of PTP1B could be a starting point to decipher the SERCA2a-NCX1-PTP1B axis in altered $\mathrm{Ca}^{2+}$ signaling-driven heart failure.

\section{SHP2}

The Scr homology-2 (SH2) domain-bearing non-transmembrane protein tyrosine phosphatase SHP2 also known as protein-tyrosine phosphatase non-receptor type 11 (PTPN11) or protein tyrosine phosphatase $2 \mathrm{C}$ (PTP-2C) is encoded by 


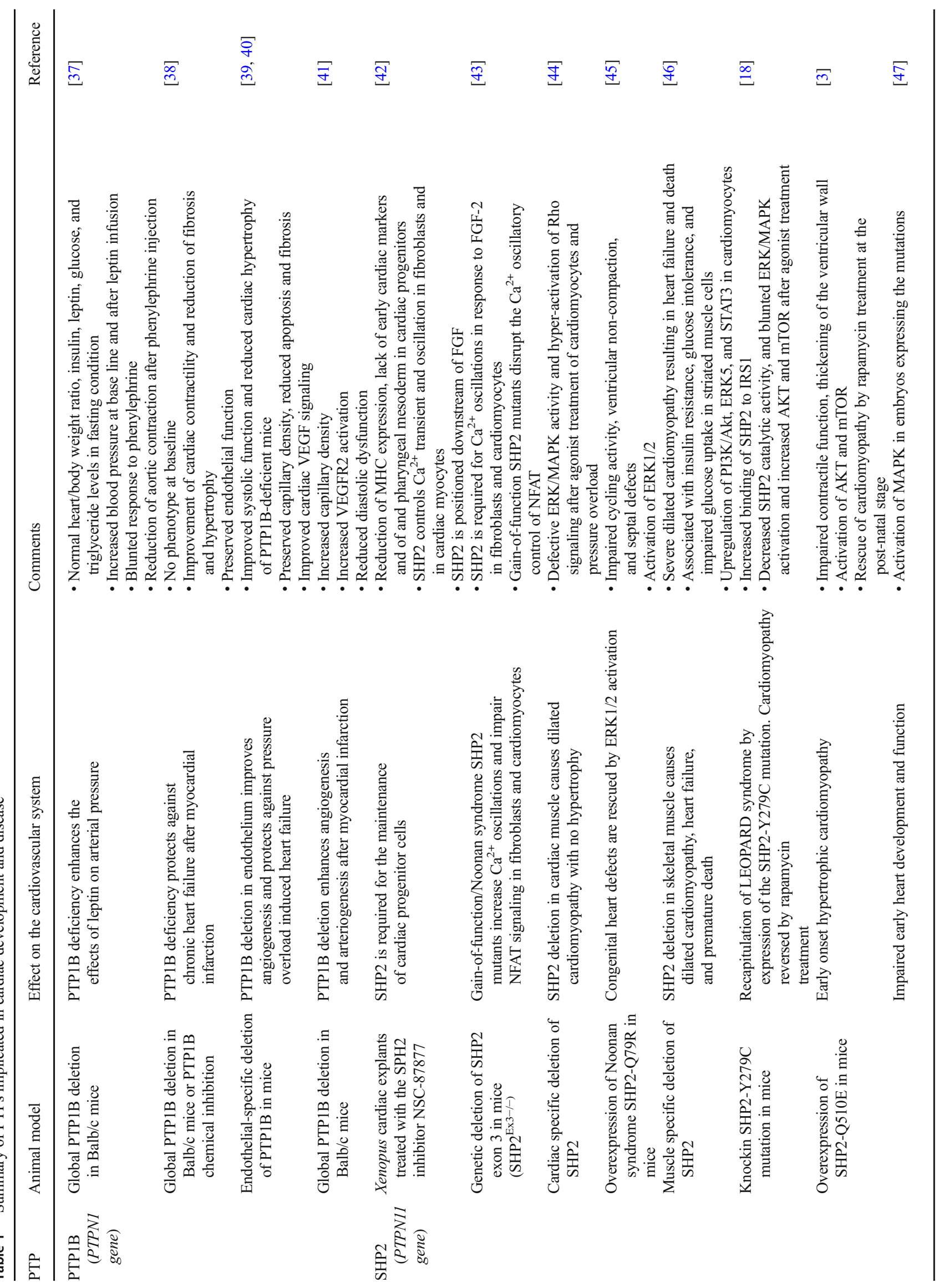




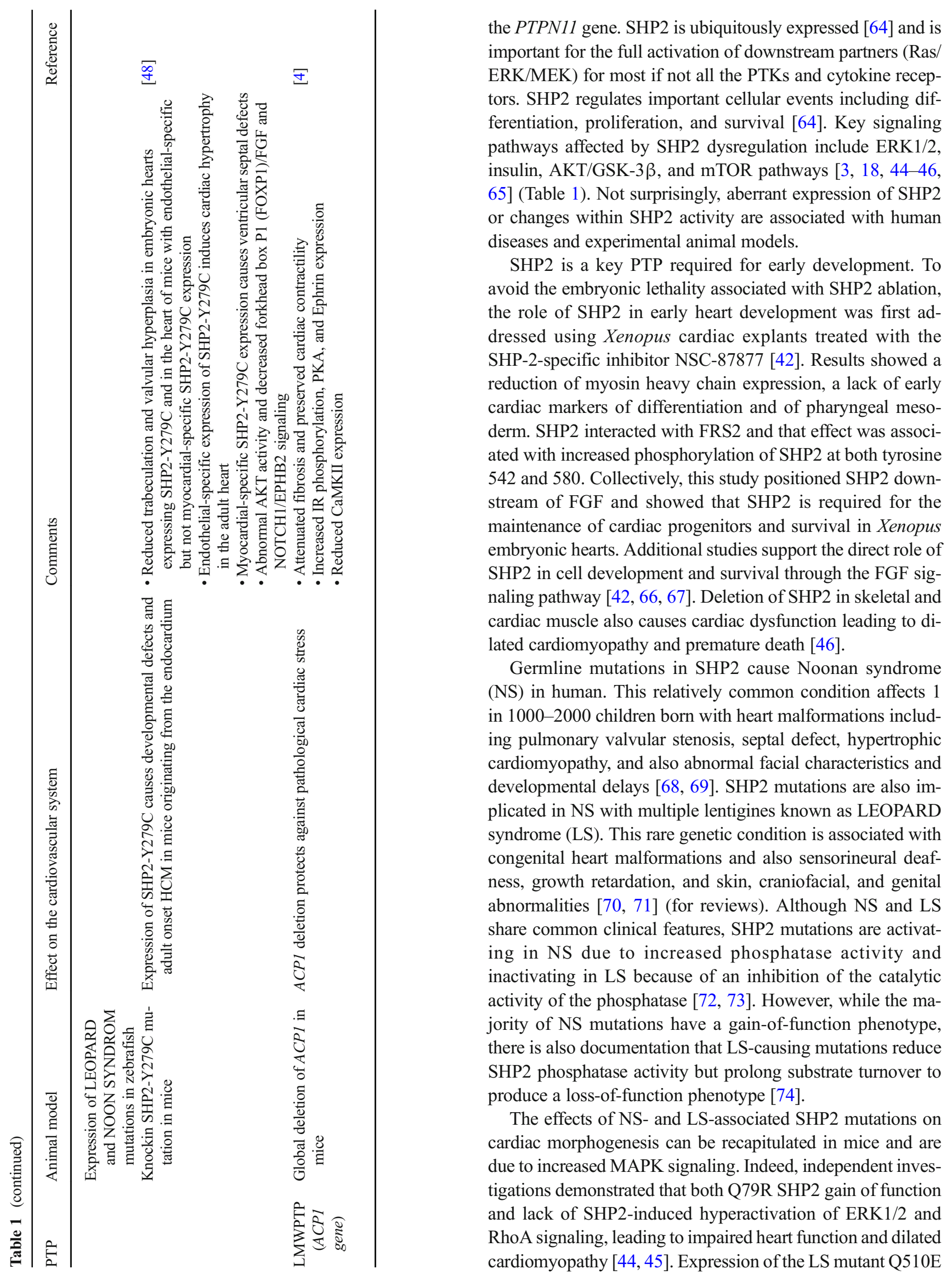




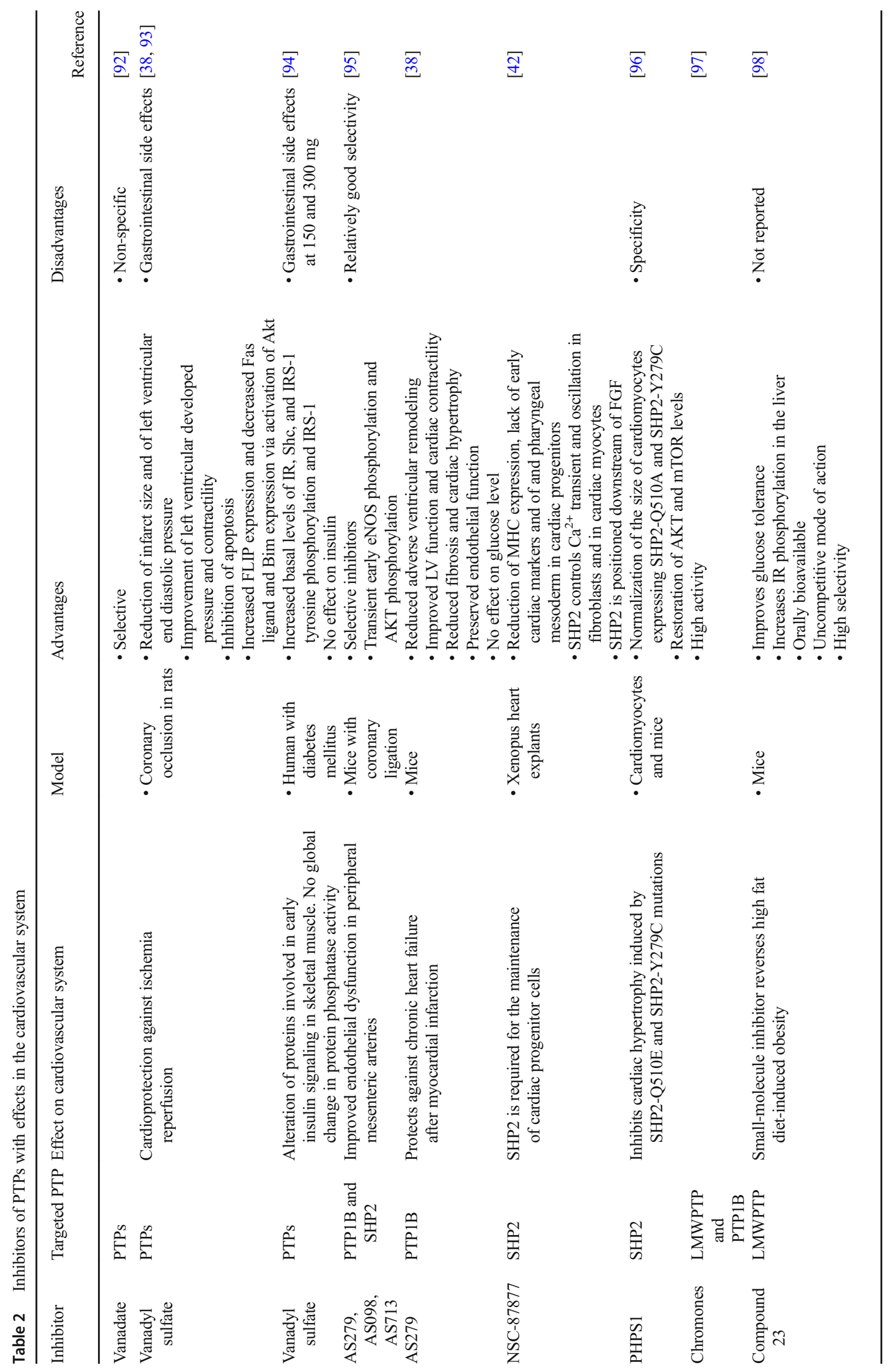


causing severe hypertrophic cardiomyopathy in infants inhibits the differentiation of P19CL6 cells in cardiomyocytes mostly due to increased Akt/GSK $3 \beta / \beta$-catenin activity $[3,18$, $44-46,65]$, and induces hypertrophic cardiomyopathy in mice through mTOR pathway [3].

Gain-of-function SHP2 mutants (R465M, E76A, D61G) enhanced $\mathrm{Ca}^{2+}$ response in cardiomyocytes through RTKs mediated $\mathrm{Ca}^{2+}$ signaling pathway but not upon activation of $\mathrm{G}$ protein-coupled receptor [43], further supporting the requirement of SHP2 in the activation of most RTK signaling. Consistent with these findings, more recent data indicate that NS and LS SHP2 variants significantly enhanced ERK activity, which partly mediated defective early cardiac development in zebrafish [47]. Furthermore, expression of Shp2Y279C, a mutation causing LS in human, recapitulated the phenotypic abnormalities seen in LS patients with signs of hypertrophic cardiomyopathy progressing to dilated cardiomyopathy and enhanced interaction of Shp2 with IRS1, and increased Akt/mTOR activity. These cardiac defects were totally reversed by treatment with the mTOR inhibitor rapamycin [18]. The developmental defects and adult-onset hypertrophic cardiomyopathy in Shp2-Y279C mutant mice correlated with increased AKT activity, inhibition of FOXP1/NOTCH1 pathways, and upregulation of NFAT activity. Dysregulated signaling originated from the endocardium indicating a reciprocal cross-talk between the endocardium and the myocardium, which is essential for heart development [48]. Such non-cell-autonomous mechanism was also triggered by overexpression of the related transcription enhancer factor-1 RTEF1 in endothelial cells, which induced cardiac hypertrophy in response to aortic constriction through an increase of VEGFB protein level [75]. Although studies of Lauriol and colleagues did not reveal enhanced expression of VEGFB mRNA level, they did not exclude a possible implication of SHP2 in NSML cardiac hypertrophy that employs this RTEF1-VEGF signaling mechanism [48].

\section{LMWPTP}

LMWPTP is a class 2 cys-based PTP encoded by the ACP1 gene located on the short arm of chromosome 2 (2p25) in the human genome and widely distributed within various tissues and organs including the heart $[10,76,77]$. LMWPTP controls a number of essential processes in mammalian cell physiology [10]. This $18 \mathrm{kDa}$ protein tyrosine phosphatase has three isoforms generated by alternative splicing. The first two isoforms produce functional proteins while the third isoform is considered a pseudogene [76, 78-80]. A decrease of both LMWPTP isoforms leads to increase in phosphorylation of the insulin receptor, Akt and PI3-K activity in the liver [81].

LMWPTP has five tyrosine residues and can be phosphorylated by tyrosine kinases such as V-src, Lck, and Fyn. Depending on the tyrosine residue phosphorylated,
LMWPTP has different phenotypes. The phosphorylation of $\mathrm{Tyr}^{131}$ residue leads to a 25 -fold increase of LMWPTP level while the phosphorylation of $\mathrm{Tyr}^{132}$ mediates the recruitment of Grb2 protein [82]. On the other hand, like other PTPs, LMWPTP can be dephosphorylated by tyrosine phosphatases, and can by itself dephosphorylate various tyrosine kinases and their respective substrates $[24,76]$.

Studies suggested that its overexpression causes increased dephosphorylation of phosphotyrosine, which may repress tyrosine kinase oncogene malignant transformation and growth factor receptor signaling [10]. LMWPTP also modulates the JAKSTAT pathway by binding and dephosphorylating STAT5 [83]. Furthermore, LMWPTP oxidation prevents dephosphorylation and inactivation of STAT2 and JAK5 [83]. In addition, LMWPTP is regulated by ROS mediated oxidation [84]. LMWPTP tyrosine residues can be oxidized by exogenous oxidative stress by glucose oxidase or sodium pervanadate in vivo [24]. Alteration of LMWPTP levels causes a reduction in enzymatic binding, glycolysis, and erythrocyte plasticity in $\mathrm{T}$ cell signaling [76]. Furthermore, an increase in LMWPTP levels was associated with protection against several conditions such as allergy, asthma, and abortion [76].

LMWPTP also acts as a negative regulator of EphA2 tyrosine phosphorylation, which regulates tumor cell growth and survival [83, 85]. LMWPTP affects cellular proliferation through reduction of FGFR tyrosine phosphorylation [24, $82,86]$ and modulates PDGF expression through its phosphatase activity [84]. Overexpression of LMWPTP markedly decreases cell growth rate as a secondary effect of PDGF reduction [24]. LMWPTP also acts as a negative regulator of insulin signaling as shown by the improved glucose and insulin tolerance of diet-induced obese mice injected with an LMWPTP antisense oligonucleotide [81].

Examination of genetic variations in the $A C P 1$ gene revealed the presence of single-nucleotide polymorphisms (SNPs) that alter the enzyme activity and the ratio of the two main protein isoforms LMPTP-A and LMPTP-B [87]. Association studies in various populations indicated a role of $A C P 1$ in metabolic syndrome and coronary artery disease [88-91]. In particular, the hypertrophic response of the myocardial wall is regulated by LMWPTP through activation of growth factors such as PDGF, IGF1, and insulin [76]. Moreover, increased LMWPTP activity reduces the metabolic rate and subsequently enhanced the demand of the hypertrophic response [76]. Consistent with this report, deletion of LMWPTP in mice confers a cardio-protective phenotype after long-term pressure overload hypertrophy [4]. The striking reduction of fibrosis and sustained cardiac function of LMWPTP knockout mice subjected to pathological stress are associated with upregulation of fetal cardiac genes, increased insulin receptor phosphorylation, and inactivation of G $\alpha \mathrm{q} / 11 / \mathrm{PLC} \beta / \mathrm{CaMKII}$ pathways. LMWPTP levels are also high in the fetal murine heart, reduced in the post-natal heart, 
and increased in patients with end-stage heart failure indicating that LMWPTP is a positive regulator of pathological cardiac hypertrophy [4].

\section{PTP inhibitors as potential new therapeutic for cardiac diseases}

PTPs play a central role in modulating physiological cardiac development [35]. Hyper-activation of the catalytic domain of PTPs initiates cardiomyopathy through the deregulation of cellular processes like proliferation [43]. Therefore, the implication of PTPs in the development of cardiomyopathies supports PTPs as potential targets for signaling-based therapeutics for these diseases. Two decades ago, vanadate and pervanadate were widely used to inhibit PTPs including PTP1B [92] (Table 2). This inhibition revealed potent and selective to PTPs but unfortunately non-specific. Subsequently, several small molecules targeting PTPs have been developed or tested with the hope to treat human pathologies including heart failure, diabetes, and cancers. Among those, vanadyl sulfate protected against ischemia-reperfusion in rats via increased FLIP and decreased Fas ligand and Bim expression secondary to AKT activation [93]. However, when tested in diabetic patients, vanadyl sulfate altered the expression of proteins involved in early insulin signaling in skeletal muscle, with no effect on protein phosphatase activity [94]. Endothelial dysfunction of peripheral arteries after short-term ischemia-induced heart failure was improved in mice after administration of AS279, AS098, and AS713 PTP1B inhibitors [95]. Compound inhibitors of PTP1B have being developed in academic laboratories and by the pharmaceutical industry and tested in animal models of obesity. Some like trodusquemine and ertiprotafib have reached phase 2 clinical trials to treat obesity and diabetes, although ertiprotafib was discontinued for lack of efficacy $[55,99]$. It remains to be seen whether PTP1B inhibition has long-term beneficial effects for the treatment of cardiovascular disorders such as congestive heart failure.

Chromones, which are derivatives of benzopyran, are a class of highly active inhibitors of LMWPTP. They also have selective inhibition towards PTP1B [97]. The findings that LMWPTP plays a role in cancer and heart failure and alters insulin signaling prompted interest to develop inhibitors of LMWPTP with high activity. A series of compounds were discovered which inhibit LMWPTP and also PTP1B [97]. Recently, several novel smallmolecule inhibitors of LMWPTP with potency and strong selectivity were discovered [100]. Also, a non-competitive small-molecule inhibitor of LMWPTP with high selectivity over other phosphatase with the ability to reverse high-fat diet-induced obesity has been reported [98]. This new inhibitor is viewed as promising for the treatment of human diseases including type 2 diabetes and heart failure. Numerous efforts have been made to identify inhibitors of SHP2 since missense mutations cause NS and LS in human. High-throughput screening identified a small molecular weight compound PHPS1 with high specificity and cell permeability [101]. PHPS1 inhibits SHP2 catalytic domain and was found to prevent the hypertrophic effect of mutant SHP2-Q510E in isolated cardiomyocytes and in mice expressing the mutant protein $[96,101]$. Since the SHP2-Q510E mutation causes an aggressive form of LS in human, it would be of interest to test whether the PHPS1 inhibitor confers cardioprotective effects in clinical settings. Compound inhibitors of SHP2 have also been identified using a computational approach [102]. One compound \#220-324 proved efficient in inhibiting SHP2-mediated signaling and proliferation of cancer cells, but whether it is an ideal inhibitor to treat the cardiomyopathy associated with SHP2 mutations remains to be seen.

\section{Challenges with PTP inhibitors}

Although recent advances are encouraging, the use of PTP inhibitors faced significant technical challenges in the early days. These were mostly due to the lack of PTP inhibitors with both specificity and strong binding activity. This was in part due to the small size of PTPs in addition to sharing a common catalytic signature motif (HCXXGXXR) responsible for the enzyme activity. For instance, NSC-87877 inhibited both Shp2 and Shp1 in vitro with the same efficacy [103]. Another important challenge still remaining today is the need to optimize and develop safer PTP inhibitors for heart failure treatment avoiding undesirable effects, in particular, cardiotoxicity. Thus, solving these technical challenges is critical before PTP inhibitors enter extensive preclinical trials to treat human heart failure.

Complementary concepts from computer-aided drug design (CADD) to 3D QSAR/structure-based design have been used in experimental assays to identify potential drugs targeting the catalytic pocket of PTPs, ligand binding, and conformational change during inhibitor interactions [104-106]. Information on the 3D crystal structure on PTPs is a key step for in silico screening of abundant inhibitors available in databases. SHP2 and PTP-1B are shown to be "druggable" molecules for treating cardiac diseases and other pathologies. However, few 3D crystal structure PTPs are currently available, thus making the computer search approach to find PTP inhibitors difficult [107-109]. PTPtargeted therapy is still in its early phase, although novel drugs are emerging for cancer treatment $[75,110,111]$. Further testing is needed to determine whether these new compounds can be used for pharmacological treatment of cardiomyopathies.

\section{Conclusion}

Growing experimental data support the role of PTPs as activators of cardiac diseases that operate through different mechanisms. This extensive work led to consider PTP family as drug targets to treat the diverse forms of cardiomyopathies. Few PTP inhibitors 
are known compared to the number of existing compounds for the treatment of such diseases. With the discovery of new compounds based on new screening strategies combined with the information on the 3D crystal structure on PTPs, one hopes that the design of drugs targeting PTPs will open a door of opportunity to treat human heart failure.

Acknowledgments This work was supported by a grant from King Abdulaziz City for Science \& Technology (10-BIO 1347-20) awarded to $\mathrm{CP}$.

\section{Compliance with ethical standards}

Conflict of interest The authors declare that they have no conflict of interest.

List of abbreviations AKT, Protein kinase B; CaMK, $\mathrm{Ca}^{2+} /$ calmodulindependent protein kinase; eNOS, Endothelial nitric oxide synthase; ERK, Extracellular signal-regulated kinase; FGFR, Fibroblast growth factor receptor; FOXP1, Forkhead box protein P1; FRS2, Fibroblast growth factor receptor substrate 2; GSK-3, Glycogen synthase kinase 3; HCM, Hypertrophic cardiomyopathy; JAK2, Janus kinase 2; JAK-STAT, Janus kinase/signal transducers and activators of transcription; mTOR, Mammalian target of rapamycin; NFAT, Nuclear factor of activated T cells; NFkB, Nuclear factor-kappa B; NOTCH1, Notch homolog 1, translocation-associated (Drosophila); P19CL6, Clone of the P19 mouse embryonal carcinoma cell line; PLC, Phospholipase C; PI3-K, Phosphoinositide 3-kinase; PDGF, Platelet-derived growth factor; RhoA, Ras homolog gene family, member A; ROS, Reactive oxygen species; RTKs, Receptor tyrosine kinases

Open Access This article is distributed under the terms of the Creative Commons Attribution 4.0 International License (http:// creativecommons.org/licenses/by/4.0/), which permits unrestricted use, distribution, and reproduction in any medium, provided you give appropriate credit to the original author(s) and the source, provide a link to the Creative Commons license, and indicate if changes were made.

\section{References}

1. Oudit GY, Kassiri Z, Zhou J, Liu QC, Liu PP, Backx PH, Dawood F, Crackower MA, Scholey JW, Penninger JM (2008) Loss of PTEN attenuates the development of pathological hypertrophy and heart failure in response to biomechanical stress. Cardiovasc Res 78(3):505-514. https://doi.org/10.1093/cvr/cvn041

2. Shen YH, Zhang L, Gan Y, Wang X, Wang J, LeMaire SA, Coselli JS, Wang XL (2006) Up-regulation of PTEN (phosphatase and tensin homolog deleted on chromosome ten) mediates p38 MAPK stress signal-induced inhibition of insulin signaling. A cross-talk between stress signaling and insulin signaling in resistin-treated human endothelial cells. J Biol Chem 281(12): 7727-7736. https://doi.org/10.1074/jbc.M511105200

3. Schramm C, Fine DM, Edwards MA, Reeb AN, Krenz M (2012) The PTPN11 loss-of-function mutation Q510E-Shp2 causes hypertrophic cardiomyopathy by dysregulating mTOR signaling. Am J Phys Heart Circ Phys 302(1):H231-H243. https://doi.org/ 10.1152/ajpheart.00665.2011

4. Wade F, Quijada P, Al-Haffar KM et al (2015) Deletion of low molecular weight protein tyrosine phosphatase (Acp1) protects against stress-induced cardiomyopathy. J Pathol 237(4):482494. https://doi.org/10.1002/path.4594
5. Wang Y (2007) Mitogen-activated protein kinases in heart development and diseases. Circulation 116(12):1413-1423. https://doi. org/10.1161/CIRCULATIONAHA.106.679589

6. Swaminathan PD, Purohit A, Hund TJ, Anderson ME (2012) Calmodulin-dependent protein kinase II: linking heart failure and arrhythmias. Circ Res 110(12):1661-1677. https://doi.org/ 10.1161/CIRCRESAHA.111.243956

7. Dhalla NS, Muller AL (2010) Protein kinases as drug development targets for heart disease therapy. Pharmaceuticals 3(7):21112145. https://doi.org/10.3390/ph3072111

8. Nicolaou P, Kranias EG (2009) Role of PP1 in the regulation of Ca cycling in cardiac physiology and pathophysiology. Front Biosci (Landmark Ed) 14:3571-3585

9. Heijman J, Dewenter M, El-Armouche A, Dobrev D (2013) Function and regulation of serine/threonine phosphatases in the healthy and diseased heart. J Mol Cell Cardiol 64:90-98. https:// doi.org/10.1016/j.yjmcc.2013.09.006

10. Alonso A, Sasin J, Bottini N, Friedberg I, Friedberg I, Osterman A, Godzik A, Hunter T, Dixon J, Mustelin T (2004) Protein tyrosine phosphatases in the human genome. Cell 117(6):699-711. https://doi.org/10.1016/j.cell.2004.05.018

11. Tonks NK (2013) Protein tyrosine phosphatases-from housekeeping enzymes to master regulators of signal transduction. FEBS J 280(2):346-378. https://doi.org/10.1111/febs.12077

12. Sugano Y, Lai NC, Gao MH, Firth AL, Yuan JXJ, Lew WYW, Hammond HK (2011) Activated expression of cardiac adenylyl cyclase 6 reduces dilation and dysfunction of the pressureoverloaded heart. Biochem Biophys Res Commun 405(3):349355. https://doi.org/10.1016/j.bbrc.2010.12.113

13. Qian J, Vafiadaki E, Florea SM, Singh VP, Song W, Lam CK, Wang Y, Yuan Q, Pritchard TJ, Cai W, Haghighi K, Rodriguez P, Wang HS, Sanoudou D, Fan GC, Kranias EG (2011) Small heat shock protein 20 interacts with protein phosphatase-1 and enhances sarcoplasmic reticulum calcium cycling. Circ Res 108(12):1429-1438. https:/doi. org/10.1161/CIRCRESAHA.110.237644

14. Oh JG, Kim J, Jang SP, Nguen M, Yang DK, Jeong D, Park ZY, Park SG, Hajjar RJ, Park WJ (2013) Decoy peptides targeted to protein phosphatase 1 inhibit dephosphorylation of phospholamban in cardiomyocytes. J Mol Cell Cardiol 56:63-71. https://doi. org/10.1016/j.yjmcc.2012.12.005

15. Fan WJ, van Vuuren D, Genade S et al (2010) Kinases and phosphatases in ischaemic preconditioning: a re-evaluation. Basic Res Cardiol 105(4):495-511. https://doi.org/10.1007/s00395-010-0086-3

16. Wittkopper K, Dobrev D, Eschenhagen T, El-armouche A (2011) Phosphatase-1 inhibitor-1 in physiological and pathological betaadrenoceptor signalling. Cardiovasc Res 91(3):392-401. https:// doi.org/10.1093/cvr/cvr058

17. Cohen P (2002) The origins of protein phosphorylation. Nat Cell Biol 4(5):E127-E130. https://doi.org/10.1038/ncb0502-e127

18. Marin TM, Keith K, Davies B, Conner DA, Guha P, Kalaitzidis D, Wu X, Lauriol J, Wang B, Bauer M, Bronson R, Franchini KG, Neel BG, Kontaridis MI (2011) Rapamycin reverses hypertrophic cardiomyopathy in a mouse model of LEOPARD syndromeassociated PTPN11 mutation. J Clin Invest 121(3):1026-1043. https://doi.org/10.1172/JCI44972

19. Tonks NK (2006) Protein tyrosine phosphatases: from genes, to function, to disease. Nat Rev Mol Cell Biol 7(11):833-846. https://doi.org/10.1038/nrm2039

20. Sacco F, Perfetto L, Castagnoli L, Cesareni G (2012) The human phosphatase interactome: an intricate family portrait. FEBS Lett 586(17):2732-2739. https://doi.org/10.1016/j. febslet.2012.05.008

21. Stoker AW (2005) Protein tyrosine phosphatases and signalling. J Endocrinol 185(1):19-33. https://doi.org/10.1677/joe.1.06069 
22. Kappert K, Peters KG, Bohmer FD et al (2005) Tyrosine phosphatases in vessel wall signaling. Cardiovasc Res 65(3):587-598. https://doi.org/10.1016/j.cardiores.2004.08.016

23. Senis YA (2013) Protein-tyrosine phosphatases: a new frontier in platelet signal transduction. J Thromb Haemost: JTH 11(10): 1800-1813. https://doi.org/10.1111/jth.12359

24. Raugei G, Ramponi G, Chiarugi P (2002) Low molecular weight protein tyrosine phosphatases: small, but smart. Cell Mol Life Sci: CMLS 59(6):941-949. https://doi.org/10.1007/s00018-002-8481$\mathrm{z}$

25. Paul S, Lombroso PJ (2003) Receptor and nonreceptor protein tyrosine phosphatases in the nervous system. Cell Mol Life Sci: CMLS 60(11):2465-2482. https://doi.org/10.1007/ s00018-003-3123-7

26. Boutros R, Lobjois V, Ducommun B (2007) CDC25 phosphatases in cancer cells: key players? Good targets? Nat Rev Cancer 7(7): 495-507. https://doi.org/10.1038/nrc2169

27. Karisch R, Fernandez M, Taylor P, Virtanen C, St-Germain JR, Jin LL, Harris IS, Mori J, Mak TW, Senis YA, Östman A, Moran MF, Neel BG (2011) Global proteomic assessment of the classical protein-tyrosine phosphatome and "Redoxome". Cell 146(5): 826-840. https://doi.org/10.1016/j.cell.2011.07.020

28. Graves JD, Krebs EG (1999) Protein phosphorylation and signal transduction. Pharmacol Ther 82(2-3):111-121. https://doi.org/10. 1016/S0163-7258(98)00056-4

29. Ostman A, Hellberg C, Bohmer FD (2006) Protein-tyrosine phosphatases and cancer. Nat Rev Cancer 6(4):307-320. https://doi. org/10.1038/nrc1837

30. Koretzky GA, Picus J, Thomas ML, Weiss A (1990) Tyrosine phosphatase CD45 is essential for coupling T-cell antigen receptor to the phosphatidyl inositol pathway. Nature 346(6279):66-68. https://doi.org/10.1038/346066a0

31. Ostergaard HL, Shackelford DA, Hurley TR, Johnson P, Hyman R, Sefton BM, Trowbridge IS (1989) Expression of CD45 alters phosphorylation of the lck-encoded tyrosine protein kinase in murine lymphoma T-cell lines. Proc Natl Acad Sci U S A 86(22): 8959-8963. https://doi.org/10.1073/pnas.86.22.8959

32. Thomas ML (1999) The regulation of antigen-receptor signaling by protein tyrosine phosphatases: a hole in the story. Curr Opin Immunol 11(3):270-276. https://doi.org/10.1016/S0952-7915(99)80044-2

33. Hanafusa H, Torii S, Yasunaga T, Matsumoto K, Nishida E (2004) Shp2, an SH2-containing protein-tyrosine phosphatase, positively regulates receptor tyrosine kinase signaling by dephosphorylating and inactivating the inhibitor Sprouty. J Biol Chem 279(22): 22992-22995. https://doi.org/10.1074/jbc.M312498200

34. Mustelin T, Alonso A, Bottini N, Huynh H, Rahmouni S, Nika K, Louis-dit-Sully C, Tautz L, Togo SH, Bruckner S, Mena-Duran AV, al-Khouri AM (2004) Protein tyrosine phosphatases in T cell physiology. Mol Immunol 41(6-7):687-700. https://doi.org/10. 1016/j.molimm.2004.04.015

35. Lauriol J, Jaffre F, Kontaridis MI (2015) The role of the protein tyrosine phosphatase SHP2 in cardiac development and disease. Semin Cell Dev Biol 37:73-81. https://doi.org/10.1016/j.semcdb. 2014.09.013

36. Lee H, Yi JS, Lawan A, Min K, Bennett AM (2015) Mining the function of protein tyrosine phosphatases in health and disease. Semin Cell Dev Biol 37:66-72. https://doi.org/10.1016/j.semcdb. 2014.09.021

37. Belin de Chantemele EJ, Muta K, Mintz J, Tremblay ML, Marrero MB, Fulton DJ, Stepp DW (2009) Protein tyrosine phosphatase $1 \mathrm{~B}$, a major regulator of leptin-mediated control of cardiovascular function. Circulation 120(9):753-763. https://doi.org/10.1161/ CIRCULATIONAHA.109.853077

38. Gomez E, Vercauteren M, Kurtz B, Ouvrard-Pascaud A, Mulder P, Henry JP, Besnier M, Waget A, Hooft van Huijsduijnen R, Tremblay ML, Burcelin R, Thuillez C, Richard V (2012)
Reduction of heart failure by pharmacological inhibition or gene deletion of protein tyrosine phosphatase 1B. J Mol Cell Cardiol 52(6):1257-1264. https://doi.org/10.1016/j.yjmcc.2012.03.003

39. Thiebaut PA, Besnier M, Gomez E, Richard V (2016) Role of protein tyrosine phosphatase $1 \mathrm{~B}$ in cardiovascular diseases. J Mol Cell Cardiol 101:50-57. https://doi.org/10.1016/j.yjmcc.2016.09.002

40. Gogiraju R, Schroeter MR, Bochenek ML, Hubert A, Münzel T, Hasenfuss G, Schäfer K (2016) Endothelial deletion of protein tyrosine phosphatase-1B protects against pressure overloadinduced heart failure in mice. Cardiovasc Res 111(3):204-216. https://doi.org/10.1093/cvr/cvw101

41. Besnier M, Galaup A, Nicol L, Henry JP, Coquerel D, Gueret A, Mulder P, Brakenhielm E, Thuillez C, Germain S, Richard V, Ouvrard-Pascaud A (2014) Enhanced angiogenesis and increased cardiac perfusion after myocardial infarction in protein tyrosine phosphatase 1B-deficient mice. FASEB J: Off Publ Fed Am Soc Exp Biol 28(8):3351-3361. https://doi.org/10.1096/fj.13-245753

42. Langdon YG, Goetz SC, Berg AE, Swanik JT, Conlon FL (2007) SHP-2 is required for the maintenance of cardiac progenitors. Development 134(22):4119-4130. https://doi.org/10.1242/dev. 009290

43. Uhlen P, Burch PM, Zito CI et al (2006) Gain-of-function/Noonan syndrome SHP-2/Ptpn11 mutants enhance calcium oscillations and impair NFAT signaling. Proc Natl Acad Sci U S A 103(7): 2160-2165. https://doi.org/10.1073/pnas.0510876103

44. Kontaridis MI, Yang W, Bence KK, Cullen D, Wang B, Bodyak N, Ke Q, Hinek A, Kang PM, Liao R, Neel BG (2008) Deletion of Ptpn11 (Shp2) in cardiomyocytes causes dilated cardiomyopathy via effects on the extracellular signal-regulated kinase/mitogenactivated protein kinase and RhoA signaling pathways. Circulation 117(11):1423-1435. https://doi.org/10.1161/ CIRCULATIONAHA.107.728865

45. Nakamura T, Colbert M, Krenz M, Molkentin JD, Hahn HS, Dorn GW II, Robbins J (2007) Mediating ERK 1/2 signaling rescues congenital heart defects in a mouse model of Noonan syndrome. $\mathrm{J}$ Clin Invest 117(8):2123-2132. https://doi.org/10.1172/JCI30756

46. Princen F, Bard E, Sheikh F, Zhang SS, Wang J, Zago WM, Wu D, Trelles RD, Bailly-Maitre B, Kahn CR, Chen Y, Reed JC, Tong GG, Mercola M, Chen J, Feng GS (2009) Deletion of Shp2 tyrosine phosphatase in muscle leads to dilated cardiomyopathy, insulin resistance, and premature death. Mol Cell Biol 29(2):378-388. https://doi.org/10.1128/MCB.01661-08

47. Bonetti M, Paardekooper Overman J, Tessadori F, Noël E, Bakkers J, den Hertog J (2014) Noonan and LEOPARD syndrome Shp2 variants induce heart displacement defects in zebrafish. Development 141(9):1961-1970. https://doi.org/10.1242/dev. 106310

48. Lauriol J, Cabrera JR, Roy A, Keith K, Hough SM, Damilano F, Wang B, Segarra GC, Flessa ME, Miller LE, Das S, Bronson R, Lee KH, Kontaridis MI (2016) Developmental SHP2 dysfunction underlies cardiac hypertrophy in Noonan syndrome with multiple lentigines. J Clin Invest 126(8):2989-3005. https://doi.org/10. 1172/JCI80396

49. Frangioni JV, Beahm PH, Shifrin V, Jost CA, Neel BG (1992) The nontransmembrane tyrosine phosphatase PTP-1B localizes to the endoplasmic reticulum via its 35 amino acid C-terminal sequence. Cell 68(3):545-560. https://doi.org/10.1016/0092-8674(92)90190-N

50. Salmeen A, Andersen JN, Myers MP, Tonks NK, Barford D (2000) Molecular basis for the dephosphorylation of the activation segment of the insulin receptor by protein tyrosine phosphatase 1B. Mol Cell 6(6):1401-1412. https://doi.org/10.1016/S1097-2765(00)00137-4

51. Egawa K, Maegawa H, Shimizu S, Morino K, Nishio Y, BryerAsh M, Cheung AT, Kolls JK, Kikkawa R, Kashiwagi A (2001) Protein-tyrosine phosphatase-1B negatively regulates insulin signaling in 16 myocytes and Fao hepatoma cells. J Biol Chem 276(13):10207-10211. https://doi.org/10.1074/jbc.M009489200 
52. Panzhinskiy E, Ren J, Nair S (2013) Protein tyrosine phosphatase 1B and insulin resistance: role of endoplasmic reticulum stress/ reactive oxygen species/nuclear factor kappa B axis. PLoS One 8(10):e77228. https://doi.org/10.1371/journal.pone.0077228

53. Feizi S (2009) Protein tyrosine phosphatase-1B (PTP1B) regulates EGF-induced stimulation of corneal endothelial cell proliferation. J Ophthalmic Vis Res 4(2):127-128

54. Cheng A, Dube N, Gu F et al (2002) Coordinated action of protein tyrosine phosphatases in insulin signal transduction. Eur $\mathrm{J}$ Biochem 269(4):1050-1059. https://doi.org/10.1046/j.00142956.2002.02756.x

55. Cho H (2013) Protein tyrosine phosphatase 1B (PTP1B) and obesity. Vitam Horm 91:405-424. https://doi.org/10.1016/B978-012-407766-9.00017-1

56. Elchebly M, Payette P, Michaliszyn E, Cromlish W, Collins S, Loy AL, Normandin D, Cheng A, Himms-Hagen J, Chan CC, Ramachandran C, Gresser MJ, Tremblay ML, Kennedy BP (1999) Increased insulin sensitivity and obesity resistance in mice lacking the protein tyrosine phosphatase-1B gene. Science 283(5407):15441548. https://doi.org/10.1126/science.283.5407.1544

57. Klaman LD, Boss O, Peroni OD, Kim JK, Martino JL, Zabolotny JM, Moghal N, Lubkin M, Kim YB, Sharpe AH, StrickerKrongrad A, Shulman GI, Neel BG, Kahn BB (2000) Increased energy expenditure, decreased adiposity, and tissue-specific insulin sensitivity in protein-tyrosine phosphatase 1B-deficient mice. Mol Cell Biol 20(15):5479-5489. https://doi.org/10.1128/MCB. 20.15.5479-5489.2000

58. Rahmouni K, Correia ML, Haynes WG et al (2005) Obesityassociated hypertension: new insights into mechanisms. Hypertension 45(1):9-14. https://doi.org/10.1161/01.HYP. 0000151325.83008.b4

59. Kalil GZ, Haynes WG (2012) Sympathetic nervous system in obesity-related hypertension: mechanisms and clinical implications. Hypertens Res: Off J Japn Soc Hypertens 35(1):4-16. https://oi.org/10.1038/hr.2011.173

60. Fang CX, Doser TA, Yang X, Sreejayan N, Ren J (2006) Metallothionein antagonizes aging-induced cardiac contractile dysfunction: role of PTP1B, insulin receptor tyrosine phosphorylation and Akt. Aging Cell 5(2):177-185. https://doi.org/10.1111/ j.1474-9726.2006.00201.x

61. Dong F, Fang CX, Yang X, Zhang X, Lopez FL, Ren J (2006) Cardiac overexpression of catalase rescues cardiac contractile dysfunction induced by insulin resistance: role of oxidative stress, protein carbonyl formation and insulin sensitivity. Diabetologia 49(6):1421-1433. https://doi.org/10.1007/s00125-006-0230-7

62. Herren DJ, Norman JB, Anderson R et al (2015) Deletion of protein tyrosine phosphatase 1B (PTP1B) enhances endothelial cyclooxygenase 2 expression and protects mice from type 1 diabetes-induced endothelial dysfunction. PLoS One 10(5): e0126866. https://doi.org/10.1371/journal.pone.0126866

63. Cui C, Merritt R, Fu L, Pan Z (2017) Targeting calcium signaling in cancer therapy. Acta Pharm Sin B 7(1):3-17. https://doi.org/10. 1016/j.apsb.2016.11.001

64. Neel BG, Gu H, Pao L (2003) The 'Shp'ing news: SH2 domain-containing tyrosine phosphatases in cell signaling. Trends Biochem Sci 28(6):284-293. https://doi.org/10.1016/ S0968-0004(03)00091-4

65. Ishida H, Kogaki S, Narita J, Ichimori H, Nawa N, Okada Y, Takahashi K, Ozono K (2011) LEOPARD-type SHP2 mutant Gln510Glu attenuates cardiomyocyte differentiation and promotes cardiac hypertrophy via dysregulation of Akt/GSK-3beta/ beta-catenin signaling. Am J Phys Heart Circ Phys 301(4): H1531-H1539. https://doi.org/10.1152/ajpheart.00216.2011

66. Chan RJ, Li Y, Hass MN, Walter A, Voorhorst CS, Shelley WC, Yang Z, Orschell CM, Yoder MC (2006) Shp-2 heterozygous hematopoietic stem cells have deficient repopulating ability due to diminished self-renewal. Exp Hematol 34(9):1230-1239. https://doi.org/10.1016/j.exphem.2006.04.017

67. Yang W, Klaman LD, Chen B, Araki T, Harada H, Thomas SM, George EL, Neel BG (2006) An Shp2/SFK/Ras/Erk signaling pathway controls trophoblast stem cell survival. Dev Cell 10(3): 317-327. https://doi.org/10.1016/j.devcel.2006.01.002

68. Noonan J, O'Connor W (1996) Noonan syndrome: a clinical description emphasizing the cardiac findings. Acta Paediatr Jpn: Overseas Ed 38(1):76-83. https://doi.org/10.1111/j.1442-200X. 1996.tb03443.x

69. Tartaglia M, Mehler EL, Goldberg R, Zampino G, Brunner HG, Kremer H, van der Burgt I, Crosby AH, Ion A, Jeffery S, Kalidas K, Patton MA, Kucherlapati RS, Gelb BD (2001) Mutations in PTPN11, encoding the protein tyrosine phosphatase SHP-2, cause Noonan syndrome. Nat Genet 29(4):465-468. https://doi.org/10. $1038 / \mathrm{ng} 772$

70. Lauriol J, Kontaridis MI (2011) PTPN11-associated mutations in the heart: has LEOPARD changed its RASpots? Trends Cardiovasc Med 21(4):97-104. https://doi.org/10.1016/j.tcm.2012.03.006

71. Tafazoli A, Eshraghi P, Koleti ZK, Abbaszadegan M (2017) Noonan syndrome - a new survey. Arch Med Sci: AMS 13(1): 215-222. https://doi.org/10.5114/aoms.2017.64720

72. Keilhack H, David FS, McGregor M, Cantley LC, Neel BG (2005) Diverse biochemical properties of Shp2 mutants. Implications for disease phenotypes. J Biol Chem 280(35): 30984-30993. https://doi.org/10.1074/jbc.M504699200

73. Kontaridis MI, Swanson KD, David FS, Barford D, Neel BG (2006) PTPN11 (Shp2) mutations in LEOPARD syndrome have dominant negative, not activating, effects. J Biol Chem 281(10): 6785-6792. https://doi.org/10.1074/jbc.M513068200

74. Yu ZH, Zhang RY, Walls CD, Chen L, Zhang S, Wu L, Liu S, Zhang ZY (2014) Molecular basis of gain-of-function LEOPARD syndrome-associated SHP2 mutations. Biochemistry 53(25): 4136-4151. https://doi.org/10.1021/bi5002695

75. Xu M, Jin Y, Song Q, Wu J, Philbrick MJ, Cully BL, An X, Guo L, Gao F, Li J (2011) The endothelium-dependent effect of RTEF-1 in pressure overload cardiac hypertrophy: role of VEGF-B. Cardiovasc Res 90(2):325-334. https://doi.org/10.1093/cvr/cvq400

76. Bottini N, Bottini E, Gloria-Bottini F, Mustelin T (2002) Lowmolecular-weight protein tyrosine phosphatase and human disease: in search of biochemical mechanisms. Arch Immunol Ther Exp 50(2):95-104

77. Chernoff J, Li HC (1985) A major phosphotyrosyl-protein phosphatase from bovine heart is associated with a low-molecularweight acid phosphatase. Arch Biochem Biophys 240(1):135145. https://doi.org/10.1016/0003-9861(85)90016-5

78. Magherini F, Giannoni E, Raugei G, Cirri P, Paoli P, Modesti A, Camici G, Ramponi G (1998) Cloning of murine low molecular weight phosphotyrosine protein phosphatase cDNA: identification of a new isoform. FEBS Lett 437(3):263-266. https://doi.org/10. 1016/S0014-5793(98)01241-1

79. Lazaruk KD, Dissing J, Sensabaugh GF (1993) Exon structure at the human ACP1 locus supports alternative splicing model for $\mathrm{f}$ and $\mathrm{s}$ isozyme generation. Biochem Biophys Res Commun 196(1):440-446. https://doi.org/10.1006/bbrc.1993.2269

80. Cirri P, Fiaschi T, Chiarugi P, Camici G, Manao G, Raugei G, Ramponi G (1996) The molecular basis of the differing kinetic behavior of the two low molecular mass phosphotyrosine protein phosphatase isoforms. J Biol Chem 271(5):2604-2607. https:// doi.org/10.1074/jbc.271.5.2604

81. Pandey SK, Yu XX, Watts LM, et al. 2007 Reduction of lowmolecular-weight protein tyrosine phosphatase expression improves hyperglycemia and insulin sensitivity in obese mice. J Biol Chem

82. Ramponi G, Manao G, Camici G, Cappugi G, Ruggiero M, Bottaro DP (1989) The $18 \mathrm{kDa}$ cytosolic acid phosphatase from bovine live has phosphotyrosine phosphatase activity on the 
autophosphorylated epidermal growth factor receptor. FEBS Lett 250(2):469-473. https://doi.org/10.1016/0014-5793(89)80778-1

83. Hoekstra E, Peppelenbosch MP, Fuhler GM (1826) The role of protein tyrosine phosphatases in colorectal cancer. Biochim Biophys Acta 2012:179-188

84. Xing K, Raza A, Lofgren S et al (2007) Low molecular weight protein tyrosine phosphatase (LMW-PTP) and its possible physiological functions of redox signaling in the eye lens. Biochim Biophys Acta 1774(5):545-555. https://doi.org/10.1016/j. bbapap.2007.03.001

85. Kikawa KD, Vidale DR, Van Etten RL, Kinch MS (2002) Regulation of the EphA2 kinase by the low molecular weight tyrosine phosphatase induces transformation. J Biol Chem 277(42):39274-39279. https://doi.org/10.1074/jbc.M207127200

86. Park EK, Warner N, Mood K, Pawson T, Daar IO (2002) Lowmolecular-weight protein tyrosine phosphatase is a positive component of the fibroblast growth factor receptor signaling pathway. Mol Cell Biol 22(10):3404-3414. https://doi.org/10.1128/MCB. 22.10.3404-3414.2002

87. Dissing J (1993) Human "red cell" acid phosphatase (ACP1) genetic, catalytic and molecular properties. PhD Thesis, Copenhagen University, Copenhagen, Denmark

88. Bottini N, MacMurray J, Peters W, Rostamkhani M, Comings DE (2002) Association of the acid phosphatase (ACP1) gene with triglyceride levels in obese women. Mol Genet Metab 77(3): 226-229. https://doi.org/10.1016/S1096-7192(02)00120-8

89. Shu YH, Hartiala J, Xiang AH, Trigo E, Lawrence JM, Allayee H, Buchanan TA, Bottini N, Watanabe RM (2009) Evidence for sexspecific associations between variation in acid phosphatase locus 1 (ACP1) and insulin sensitivity in Mexican-Americans. J Clin Endocrinol Metab 94(10):4094-4102. https://doi.org/10.1210/jc. 2008-2751

90. Banci M, Saccucci P, D'Annibale F et al (2009) ACP1 genetic polymorphism and coronary artery disease: an association study. Cardiology 113(4):236-242. https://doi.org/10.1159/000203405

91. Bottini E, Gloria-Bottini F, Borgiani P (1995) ACP1 and human adaptability. 1. Association with common diseases: a case-control study. Hum Genet 96(6):629-637. https://doi.org/10.1007/ BF00210290

92. Huyer G, Liu S, Kelly J, Moffat J, Payette P, Kennedy B, Tsaprailis G, Gresser MJ, Ramachandran C (1997) Mechanism of inhibition of protein-tyrosine phosphatases by vanadate and pervanadate. J Biol Chem 272(2):843-851. https://doi.org/10. 1074/jbc.272.2.843

93. Bhuiyan MS, Takada Y, Shioda N, Moriguchi S, Kasahara J, Fukunaga K (2008) Cardioprotective effect of vanadyl sulfate on ischemia/reperfusion-induced injury in rat heart in vivo is mediated by activation of protein kinase $\mathrm{B}$ and induction of FLICEinhibitory protein. Cardiovasc Ther 26(1):10-23. https://doi.org/ 10.1111/j.1527-3466.2008.00039.x

94. Goldfine AB, Patti ME, Zuberi L, Goldstein BJ, LeBlanc R, Landaker EJ, Jiang ZY, Willsky GR, Kahn CR (2000) Metabolic effects of vanadyl sulfate in humans with non-insulin-dependent diabetes mellitus: in vivo and in vitro studies. Metab Clin Exp 49(3):400-410. https://doi.org/10.1016/S0026-0495(00)90418-9

95. Vercauteren M, Remy E, Devaux C, Dautreaux B, Henry JP, Bauer F, Mulder P, Hooft van Huijsduijnen R, Bombrun A, Thuillez C, Richard V (2006) Improvement of peripheral endothelial dysfunction by protein tyrosine phosphatase inhibitors in heart failure. Circulation 114(23):2498-2507. https://doi.org/10. 1161/CIRCULATIONAHA.106.630129

96. Schramm C, Edwards MA, Krenz M (2013) New approaches to prevent LEOPARD syndrome-associated cardiac hypertrophy by specifically targeting Shp2-dependent signaling. J Biol Chem 288(25):18335-18344. https://doi.org/10.1074/jbc.M113.483800
97. Forghieri M, Laggner C, Paoli P, Langer T, Manao G, Camici G, Bondioli L, Prati F, Costantino L (2009) Synthesis, activity and molecular modeling of a new series of chromones as low molecular weight protein tyrosine phosphatase inhibitors. Bioorg Med Chem 17(7):2658-2672. https://doi.org/10.1016/j.bmc.2009.02.060

98. Stanford SM, Aleshin AE, Zhang V, et al. 2017 Diabetes reversal by inhibition of the low-molecular-weight tyrosine phosphatase. Nat Chem Biol

99. Lantz KA, Hart SG, Planey SL et al (2010) Inhibition of PTP1B by trodusquemine (MSI-1436) causes fat-specific weight loss in diet-induced obese mice. Obesity 18(8):1516-1523. https://doi. org/10.1038/oby.2009.444

100. He R, Wang J, Yu ZH, et al. (2016) Inhibition of low molecular weight protein tyrosine phosphatase by an induced-fit mechanism. J Med Chem

101. Hellmuth K, Grosskopf S, Lum CT, Wurtele M, Roder N, von Kries JP, Rosario M, Rademann J, Birchmeier W (2008) Specific inhibitors of the protein tyrosine phosphatase Shp2 identified by high-throughput docking. Proc Natl Acad Sci U S A 105(20):7275-7280. https://doi.org/10.1073/pnas.0710468105

102. Yu B, Liu W, Yu WM, Loh ML, Alter S, Guvench O, MacKerell AD, Tang LD, Qu CK (2013) Targeting protein tyrosine phosphatase SHP2 for the treatment of PTPN11-associated malignancies. Mol Cancer Ther 12(9):1738-1748. https://doi.org/10.1158/15357163.MCT-13-0049-T

103. Chen L, Sung SS, Yip ML, Lawrence HR, Ren Y, Guida WC, Sebti SM, Lawrence NJ, Wu J (2006) Discovery of a novel shp2 protein tyrosine phosphatase inhibitor. Mol Pharmacol 70(2):562570. https://doi.org/10.1124/mol.106.025536

104. Sippl W (2002) Development of biologically active compounds by combining 3D QSAR and structure-based design methods. J Comput Aided Mol Des 16(11):825-830. https://doi.org/10.1023/ A:1023888813526

105. Yu WM, Guvench O, Mackerell AD et al (2008) Identification of small molecular weight inhibitors of Src homology 2 domaincontaining tyrosine phosphatase 2 (SHP-2) via in silico database screening combined with experimental assay. J Med Chem 51(23): 7396-7404. https://doi.org/10.1021/jm800229d

106. Sobhia ME, Paul S, Shinde R et al (2012) Protein tyrosine phosphatase inhibitors: a patent review (2002-2011). Expert Opin Ther Patents 22(2):125-153. https://doi.org/10.1517/13543776.2012. 661414

107. Hof P, Pluskey S, Dhe-Paganon S, Eck MJ, Shoelson SE (1998) Crystal structure of the tyrosine phosphatase SHP-2. Cell 92(4): 441-450. https://doi.org/10.1016/S0092-8674(00)80938-1

108. Lee JO, Yang H, Georgescu MM, di Cristofano A, Maehama T, Shi Y, Dixon JE, Pandolfi P, Pavletich NP (1999) Crystal structure of the PTEN tumor suppressor: implications for its phosphoinositide phosphatase activity and membrane association. Cell 99(3):323-334. https://doi.org/10.1016/S0092-8674(00)81663-3

109. Wiesmann C, Barr KJ, Kung J, Zhu J, Erlanson DA, Shen W, Fahr BJ, Zhong M, Taylor L, Randal M, McDowell RS, Hansen SK (2004) Allosteric inhibition of protein tyrosine phosphatase 1B. Nat Struct Mol Biol 11(8):730-737. https://doi.org/10.1038/nsmb803

110. Scott LM, Chen L, Daniel KG, Brooks WH, Guida WC, Lawrence HR, Sebti SM, Lawrence NJ, Wu J (2011) Shp2 protein tyrosine phosphatase inhibitor activity of estramustine phosphate and its triterpenoid analogs. Bioorg Med Chem Lett 21(2):730-733. https:// doi.org/10.1016/j.bmcl.2010.11.117

111. Scott LM, Lawrence HR, Sebti SM et al (2010) Targeting protein tyrosine phosphatases for anticancer drug discovery. Curr Pharm Des 16(16):1843-1862. https://doi.org/10.2174/ 138161210791209027 